\title{
The Effect of Group Counseling on Self Management Technique to Managing Difficulty of Time Management on Students of Senior High School Medan
}

\author{
Rahmulyani $^{1 *}$, Salmah Fitriyani Nasution ${ }^{2}$, Nasrun $^{3}$, Nani Barorah ${ }^{4}$, \\ Nindya Ayu Pristanti ${ }^{5}$, Miswanto ${ }^{6}$ \\ ${ }^{1-6)}$ Guidance and Counseling Department, Universitas Negeri Medan, Indonesia \\ *rahmulyani@yahoo.co.id
}

\begin{abstract}
This research purpose is to determine the effect of group counseling services with the technique of self management on managing difficulty of time management on Class X student of SMA Negeri 3 Medan (Senior High School). This study was a quantitative research with quasi-experimental type with pretest-posttest one group design. The research data was collected with questionnaires about the difficulty on managing learning time with total 28 items that were valid and reliable statements then the data was analized using the Wilcoxon test. From the analysis, it is obtained $\mathrm{J}_{\text {count }}=6$ with $\alpha=0.05$, while $\mathrm{J}_{\text {tabel }}=4$. (ho rejected) The pre-test data manages learning time an average score of 78.25 , while the post-test manages the learning time obtained an average score of 88 . The result show that after receiving group counseling services with self management techniques is higher than before getting group counseling services with self management techniques.
\end{abstract}

Keywords: counseling, self management, difficulties, managing learning time

\section{Introduction}

The law on National Education System No. 20 of 2003 article 3 concerning national education has explained the demand for a student on extensive knowledge, morality, independence and responsibility. These demands can be achieved by learning, because the way of learning will be obtained by learning a new knowledge or information that can provide changes to the way of student thinking [1].

According to Mujiyono, time management is planning, organizing, driving and carrying out time productivity. Time management is a daily process that is used to distribute the time, make a schedule, list things to do task completion, and other systems that help to use time effectively [2]. In a research journal conducted by Nurhidayati [2], the results of List of Problems Check of student that conducted on students showed the highest percentage of students' learning habits problems compared to several other problems. The average results analysis showed that around $58 \%$ on of student indicate a learning habits problems. Most of the problems are, students feel sleepy while studying $(30.30 \%)$, students only learn at night (18.18\%), students do not have regular study time (15.15\%), often feel lazy learning $(12.12 \%)$, students find it difficult to remember lessons that have been memorized $(9.09 \%)$, students learn when there is a test $(6.06 \%)$, and cannot apply good learning methods $(3.03 \%)$.

It also proven of the results of interview made while exercising the PPL-T in SMA Negeri 3 Medan with teachers and teacher of counselling. Teacher said that they found 
their students who experience difficulties in managing or developing a schedule time for learning efficiently. Learning is also not only about classes in schools, but also in various non-formal institutions, The results of the previous study and interview show that one of the problems in learning habits is that students do not have an understanding of time management.

Counseling as a learning process has an effort to develop positive, affective, and psychomotor aspects in which the client matches the problems he faces. One of counseling form itself is a group counseling by Pauline Harrison 2002 [3], Group counseling is counseling that consists of 4-8 1-2 counselee who met with counselors. In the process, group counseling discuss keeping problems, such as the ability to build relationships and communication, developing self-esteem, and skills in addressing the problem.

Erlangga quotes Komalasari [4], one of the technique used by researchers in conducting group counseling is the technique of self management is a strategy of behavior change or regulation and monitoring carried out by the client himself in the form of self-monitoring exercises. stimulation control, and giving appreciation to self. This Research pupose to explore the effect of group counseling services with the technique of self management on managing difficulty of time management on class X student of SMA Negeri 3 Medan.

\section{Research Method}

The type of this research is quasi experiment. The method of Quasi exsperiment design, which is difficult to implement. It has a control group, but it cannot function fully to control external variables that affect the conduct of experiments. The design used in this study was to use the design of one group pre-test and post-test design. According to the Jakni [5] design of pre-test and post-test group has the following pattern :

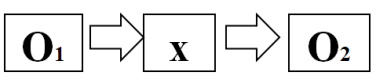

$\mathrm{O}_{1}:$ Pre - test $\mathrm{t}$ (before being given treatment / treatment $)$

$\mathrm{X}$ : Treatment ( Treatment)

$\mathrm{O}_{2}:$ Post - test (after treatment / treatment)

The subjects were students of class 8 class X SMA Negeri 3 Medan, academic year 2018/2019. Using technique of random sampling on collecting samples. Data analysis technique the Wilcoxon test was used to determine whether there was any influence on the difficulty of managing study time after being group counseling services with self management techniques. Data in this study were obtained by measuring the management of students' learning time before implementing group counseling services with self management techniques ( pre-test) and after implementing group counseling service with self management ( post-test) techniques This study used non-paramatic statistics to analyze data. The reason for using it is because of the small sample of researchers.

\section{Results and Discussion}

Based on the results of the study, it was found that group counseling with self management techniques on the difficulty of managing student learning time. levels marked positive $=30$ and the number of levels marked negative is $=6$. So, the value of $J=6$ is the number of smaller levels. 
From the further analysis it found that there is small value of $\mathrm{J}$, which is 6 , so $\mathrm{J}$ count $=6$, with $\alpha=0.05$ and $n=8$ so that the value of $J$ table is 4 . From the data it appears that $J_{\text {count }}>$ $\mathrm{J}_{\text {table where }} 6>4$, this means that managing student learning time before and after the group counseling services with self-management techniques treatment is has some change. In this case students who have received group counseling services with self management techniques have a higher management of learning time.

Based on jum analysis it found that the score of pre-test 626 and a score of post-test 704 then the difference between a score of 78. The highest score of pre-test is 93 and the highest score of post-test is 99 . Therefore the difference in score amounted to 6 and the lowest scores on the pre-test is 66 and scores the lowest post-test is 77, which the difference in scores is 11 . Thus the average score of the pre-test is 78.25 and the post-test score is 88 , the difference in the average score is 78 .

Thus based on the purpose of this study to determine the effect of group counseling services with self management techniques on the difficulty of managing study time, the researchers have found that there is an influence of group counseling services with self management techniques on the difficulty of managing study time. Group counseling services with self management techniques are an alternative to efforts to remind students to manage the learning time of class X students at Medan.

\section{Conclusion}

Based on the results of this study it can be suggested to several parties, including:

1) For the school, it is expected that the principal can move the guidance and counseling teacher to apply group counseling with self management techniques to the difficulty of managing student learning time

2) School counselour need to to improve counseling services, especially group theory group behavioral counseling techniques self managemant in improving student learning

\section{References}

[1] Daharnis, Nitami \& Yusri. (2015). Relationships Motivation dengan Academic Procrastination Students. J. Counselor, pp.1-12. http://ejournal.unp.ac.id/ index.php/konselor/article/view/6449/5099 . Accessed on December 3, 2018, at 02.00.

[2] Nurhidayati. (2015), Enhancing the Understanding of Time Management through Group Guidance with the Problem Solving Technique for Students. Psychopedagogia, pp. 24-

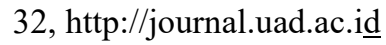

[3] Kurnanto, M. Edi. (2013), Group Counseling. Bandung: Alfabeta.

[4] Isnaini, Faiqotul. (2014). Self Management Strategy to Impove Study Dicipline for Student Class VIII Ceria Morgoyoso Pati Middle High School. http://eprints.ums.ac.id/ $31535 / 13 / 2$,

[5] Jakni. (2016), Experiment Research Method on Education. Bandung: Alfabeta. 